\title{
HBV Prevention and Treatment in Countries of Central Asia and the Caucasus
}

\author{
Daulet Amerzhanov ${ }^{1}$, Indira Suleimenova ${ }^{1}$, Salima Davlidova ${ }^{1}$, Zhamilya Nugmanova ${ }^{2}$ \\ and Syed Ali ${ }^{1, *}$ \\ 1 Nazarbayev University School of Medicine, Nur-Sultan 010000, Kazakhstan; \\ damerzhanov@nu.edu.kz (D.A.); indira.suleimenova@nu.edu.kz (I.S.); salima.davlidova@nu.edu.kz (S.D.) \\ 2 Kazakh National Medical University, Almaty 050000, Kazakhstan; zhamilya.nugmanova@gmail.com \\ * Correspondence: syed.ali@nu.edu.kz
}

Received: 6 August 2020; Accepted: 8 September 2020; Published: 30 September 2020

\begin{abstract}
The countries of Central Asia and the Caucasus are linked by travel and trade, which is promoted by visa-free mobility across borders. Unfortunately, this migrant mobility has given rise to the transmission of various infections within this region. Overlaps in culture, tradition, and behavior among these countries provide opportunities to share experiences that have proven effective in controlling transmission. Here we present a review of hepatitis B virus (HBV) prevalence, prevention and treatment across Central Asia and the Caucasus. Overall, owing to effective measures, while HBV prevalence has been steadily declining in the region, certain gaps still exist regarding the generation and availability of HBV infection data.
\end{abstract}

Keywords: Central Asia; Caucasus; HBV

\section{Introduction}

Following the collapse of the Soviet Union in 1991, 15 countries gained independence: Armenia, Azerbaijan, Belarus, Estonia, Georgia, Kazakhstan, Kyrgyzstan, Latvia, Lithuania, Moldova, Russia, Tajikistan, Turkmenistan, Ukraine, and Uzbekistan [1]. Some of these countries are historically grouped based on the administrative classification used during the period of the Russian Empire. Central Asia includes Kazakhstan, Kyrgyzstan, Tajikistan, Turkmenistan, and Uzbekistan, while another sub-region is the Caucasus, which comprises Armenia, Azerbaijan and Georgia, and part of Russia also known as Northern Caucasus [2] (Figure 1). Countries in Central Asia and the Caucasus share common history leading to anthropological similarities in their societies, economic growth, and issues [3]. Open border policy within the Former Soviet Union (FSU) region promoted travel and trade on the one hand, but has, on the other, facilitated the transmission of infectious diseases. Overlaps in culture and tradition, and similarities in behavior and practices associated with infection transmission, provide opportunities to share and adapt the experiences that have proven effective in the control and treatment of infections across the region. 


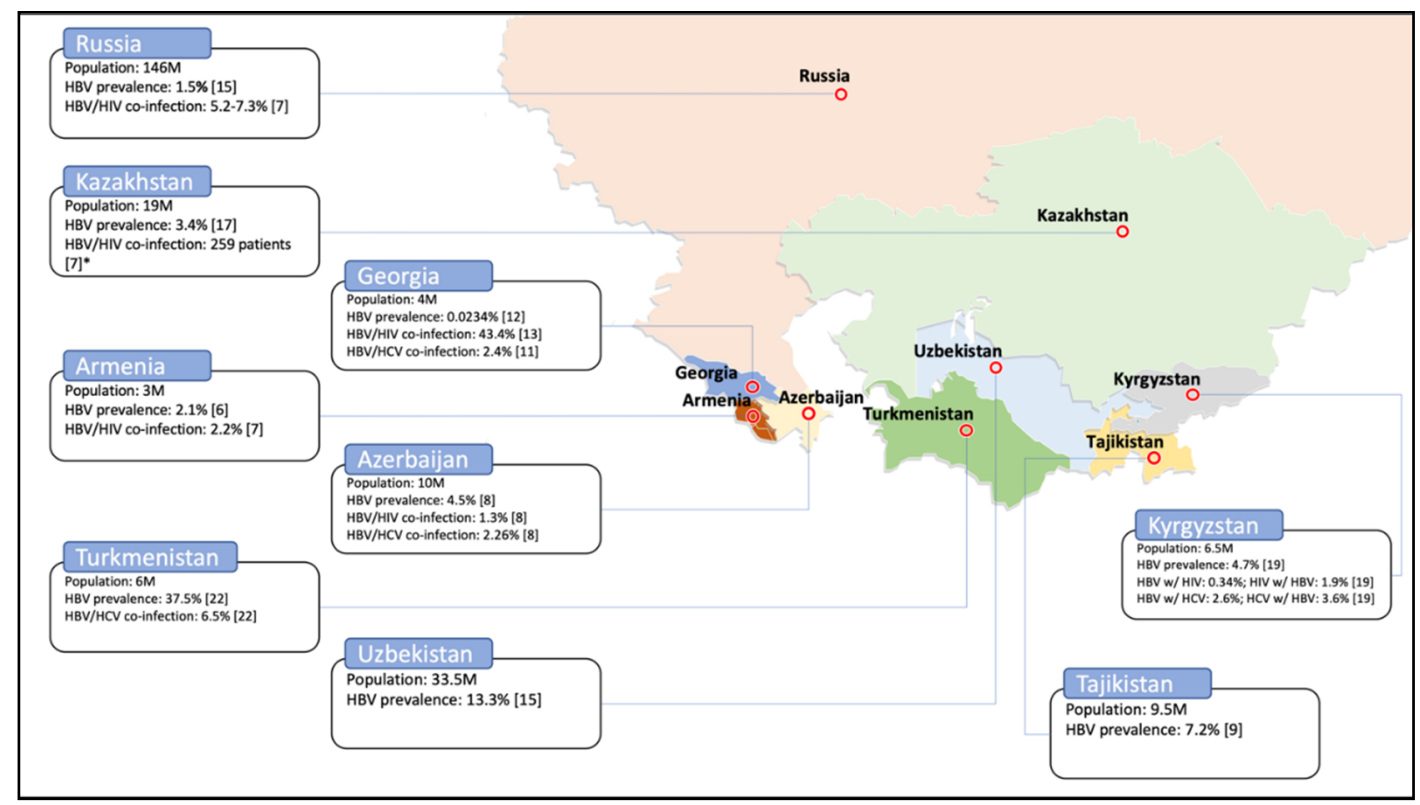

Figure 1. Prevalence of hepatitis B virus (HBV) and co-infections of HBV/HIV and HBV/HCV. Total population for each country [4] is mentioned along with the prevalence of single and double infections, wherever available. The map template was taken from the source [5].

In this article, we provide an overview of the prevalence, control, and treatment of hepatitis B virus (HBV) infection among the nine countries of Central Asia and the Caucasus. We review the policies implemented by the governments for the prevention and treatment of $\mathrm{HBV}$, and highlight areas that have worked in certain countries and may be adapted by others.

\section{Prevalence}

The prevalence of hepatitis B infection in Armenia significantly increased from $<2 \%$ to $8 \%$ between 2000 and 2007 [6,7]. This may be explained by improved sensitivity of diagnostic tools or that of prevalence surveys. However, single HBV and HBV/HIV co-infection dropped to 2\% in 2012 [8] and 2017 [9], respectively (Figure 1 and Table 1). In Azerbaijan, prevalence of hepatitis B infection decreased from $8 \%$ in 2007 [6] to $4.5 \%$ in 2012 [10]. Encouragingly, this number dropped to $2.8 \%$ in 2017 [11], highlighting effective implementation of routine immunization. In 2012, the HBV/HIV and $\mathrm{HBV} / \mathrm{HCV}$ co-infection rates among the Azerbaijani population was estimated at $1.3 \%$ each [10]. In Georgia, the prevalence of hepatitis B was estimated at 3.4\% in 2001 [12]. In a study conducted in 2005 amongst the general population, $\mathrm{HBc}$ antibodies and hepatitis B surface antigen (HBsAg) were found in, respectively, $11.4 \%$ and $1.1 \%$ of study participants [13]. Finally, a study in 2013 reported a significant decrease in HBV prevalence, i.e., 23.4 cases in a 100,000 population (i.e., 0.0234\%) (Table 1) [14]. In Georgia, the rate of HBV/HCV co-infection was reported as 2.4\% in 2005 [13]. In Georgia, a study of $\mathrm{HBV}$ co-infection in HIV-positive individuals showed the presence of anti-HBc and $\mathrm{HBsAg}$ in $43.42 \%$ and $6.86 \%$ of the population, respectively [15]. Hepatitis B prevalence in the general Kazakhstani population was reported to be $10 \%$ in 2007 [6]. In 2012, the prevalence among voluntary blood donors was estimated at $2 \%$ [16]. One year later, in 2013, this number declined to $3.8 \%$ among the general population, and to $1.8 \%$ among the Kazakhstani first-time blood donors [17]. In 2014, the prevalence among the blood donors declined to $1 \%$ [18], and in 2016, to 3.4\% among the South Kazakhstan Province's population [19]. In 2017, HBV/HIV co-infection was reported in 259 individuals. Since the sample size for this survey was not provided, it was not possible to calculate the prevalence [9]. Between 2013 and 2015, hepatitis B prevalence was estimated at 3.6\% among voluntary blood donors in Kyrgyzstan [20]. This number among the general Kyrgyzstani population was assessed at $4.7 \%$ in 2015 [21], and 6.6\% in 2017 [9]. In 2017, HIV prevalence among HBV patients was reported to be 
$0.34 \%$, whereas HBV prevalence among HIV patients was 1.9\% [20]. In patients with HBV infection, the co-infection rate with HCV was $2.6 \%$, while in patients with HCV infection, the co-infection rate with HBV was 3.6\% [20]. In the general population of the Russian Federation, hepatitis B prevalence was estimated at $1.5 \%$ in 2013 [17]. In 2016, the prevalence varied between $1 \%$ and $8 \%$ in six different Russian regions [22]. The HBV/HIV co-infection rate was assessed at between 5\% and 7\% in 2017 [9]. In 2017, hepatitis B prevalence in the Tajikistani general population was estimated at 7\% [11], whereas among Tajik migrant workers in Russia, it was 5\% in 2017 [23]. In Turkmenistan, between 2010 and 2012, hepatitis B infection was estimated to be the second most prevalent after HCV among the patients of the Center for Infectious Diseases. It was reported that 460 out of 1228 surveyed patients, i.e., $37.5 \%$, had the HBV infection [24]. The rate of HBV/HCV co-infection among all known hepatitis patients in Turkmenistan was 6.5\% between 2010 and 2012 [24]. The prevalence of hepatitis B in the general Uzbekistani population was 13\% in 2013 [17], declining to $>10 \%$ in 2017 [9]. The same prevalence in Uzbek migrant workers in Russia was estimated at 4\% [23] (Figure 1 and Table 1). Possibly owing to improved surveillance and immunization, Azerbaijan, Georgia, Kazakhstan, Kyrgyzstan, Tajikistan, and Uzbekistan have experienced a steady decline in HBV prevalence during the last two decades (Table 1)—commendable examples for the rest of the countries in this region. These patterns are comparable to the ones reported for the European region, where HBV prevalence has been reported to vary between $0.1 \%$ to $4.4 \%$ [25].

Table 1. Prevalence of HBV and co-infections of HBV/HIV and HBV/HCV. Prevalence of single and double infections, wherever available, is mentioned along with the source. In all the studies, prevalence was measured by the presence of hepatitis B surface antigen (HBsAg) in the blood. * Prevalence of anti-HBc antibodies in HIV-positive individuals. ${ }^{* *}$ Prevalence of HBsAg in HIV-positive individuals. *** The source mentions the number of HBV/HIV infected patients without mentioning the sample size. $\mathrm{n} / \mathrm{a}$, not available.

\begin{tabular}{|c|c|c|c|c|c|c|}
\hline \multirow{2}{*}{ Country } & \multicolumn{2}{|c|}{ HBV } & \multicolumn{2}{|c|}{ Co-Infection HBV/HIV } & \multicolumn{2}{|c|}{ Co-Infection HBV/HCV } \\
\hline & Prevalence & Year & Prevalence & Year & Prevalence & Year \\
\hline \multirow{3}{*}{ Armenia } & $2.1 \%$ & $2012[8]$ & \multirow{3}{*}{$2.2 \%$} & \multirow{3}{*}{2017 [9] } & \multirow{3}{*}{$\mathrm{n} / \mathrm{a}$} & \multirow{3}{*}{$\mathrm{n} / \mathrm{a}$} \\
\hline & $8 \%$ & 2007 [6] & & & & \\
\hline & $<2 \%$ & $2000[7]$ & & & & \\
\hline \multirow{4}{*}{ Azerbaijan } & $2.8 \%$ & $2017[11]$ & \multirow{4}{*}{$1.3 \%$} & \multirow{4}{*}{2012 [10] } & \multirow{4}{*}{$2.26 \%$} & \multirow{4}{*}{2012 [10] } \\
\hline & $4.5 \%$ & $2012[10]$ & & & & \\
\hline & $0.02 \%$ & $2010[26]$ & & & & \\
\hline & $8 \%$ & $2007[6]$ & & & & \\
\hline \multirow{3}{*}{ Georgia } & $0.0234 \%$ & 2013 [14] & $43.42 \%$ * & \multirow[t]{2}{*}{2008 [15] } & \multirow{3}{*}{$2.4 \%$} & \multirow{3}{*}{2005 [13] } \\
\hline & $1.1 \%$ & 2005 [13] & & & & \\
\hline & $3.4 \%$ & $2001[12]$ & $6.86 \% * *$ & 2008 [15] & & \\
\hline \multirow{6}{*}{ Kazakhstan } & $3.4 \%$ & 2016 [19] & \multirow{6}{*}{$n=259 * * *$} & \multirow{6}{*}{2017 [9] } & \multirow{6}{*}{$\mathrm{n} / \mathrm{a}$} & \multirow{6}{*}{$\mathrm{n} / \mathrm{a}$} \\
\hline & $1.12 \%$ & 2015 [18] & & & & \\
\hline & $2.1 \%$ & 2015 [16] & & & & \\
\hline & $1.8 \%$ & \multirow{2}{*}{2014 [17] } & & & & \\
\hline & $3.8 \%$ & & & & & \\
\hline & $10 \%$ & 2007 [6] & & & & \\
\hline \multirow{3}{*}{ Kyrgyzstan } & $4.7 \%$ & 2017 [21] & \multirow{3}{*}{$\begin{array}{l}\text { HBV w/HIV: } 0.34 \% \\
\text { HIV w/HBV: } 1.9 \%\end{array}$} & \multirow{3}{*}{2017 [20] } & \multirow{3}{*}{$\begin{array}{l}\text { HBV w/HCV: } 2.6 \% \\
\text { HCV w/HBV: } 3.6 \%\end{array}$} & \\
\hline & $3.6 \%$ & 2017 [20] & & & & 2017 [20] \\
\hline & $6.6 \%$ & 2017 [9] & & & & \\
\hline Russian Federation & $1.2-8.2 \%$ & 2016 [22] & $5.2-7.3 \%$ & 2017 [9] & $\mathrm{n} / \mathrm{a}$ & $\mathrm{n} / \mathrm{a}$ \\
\hline & $1.5 \%$ & 2014 [17] & & & & \\
\hline Tajikistan & $5.3 \%$ & 2017 [23] & 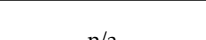 & pla & a & pla \\
\hline & $7.2 \%$ & $2017[11]$ & $\mathrm{n} / \mathrm{a}$ & $\mathrm{n} / \mathrm{a}$ & $\mathrm{n} / \mathrm{a}$ & $\mathrm{n} / \mathrm{a}$ \\
\hline Turkmenistan & $37.5 \%$ & 2018 [24] & $\mathrm{n} / \mathrm{a}$ & $\mathrm{n} / \mathrm{a}$ & $6.5 \%$ & 2018 [24] \\
\hline & $4.1 \%$ & 2017 [23] & & & & \\
\hline Uzbekistan & $>10 \%$ & 2017 [9] & $\mathrm{n} / \mathrm{a}$ & $\mathrm{n} / \mathrm{a}$ & $\mathrm{n} / \mathrm{a}$ & $\mathrm{n} / \mathrm{a}$ \\
\hline & $13.3 \%$ & 2014 [17] & & & & \\
\hline
\end{tabular}




\section{Blood Donor Screening}

As a bloodborne pathogen, HBV transmits readily through injection needles and blood transfusions. The safety of donated blood and its products is ensured by implementation of rigorous screening protocols by the blood banks [27]. According to the last reports in 2016 and 2011, blood donated in Armenia [28] and Georgia [12], respectively, was screened for hepatitis B; however, exact screening techniques used in the countries are not specified (Table 2). In Azerbaijan, donated blood products were tested for hepatitis B surface antigen (HBsAg) by 2011 [29]. According to the Kazakhstani law adopted in 2019, a laboratory study of donated blood samples for hepatitis B is carried out in two stages [30]. The first stage includes a screening for the presence of $\mathrm{HBsAg}$, while the second stage involves HBV nucleic acid testing (NAT), that allows detection of the virus during its window period [30]. The second-stage testing is performed only if the first stage screening yields a negative result [30]. If the results of HBsAg serological screening and HBV nucleic acid testing are both negative, the sample is considered to be HBV-negative and acceptable for transfusion [30]. However, if the serological screening for HBsAg is positive, then two additional tests and one confirmatory test are performed. The first additional test for HBsAg is carried out using the same reagents as the previous one, while the second additional screening for HBsAg is performed using a kit from a different manufacturer [30]. The final confirmatory test is performed using an HBsAg neutralization reaction. If all three additional and confirmatory tests are negative, the blood sample is considered to be HBV-negative, however, the donor is suspended from blood donation for 6 months. Only after conducting a control test consisting of the two above-mentioned stages and receiving a negative result, is the donor allowed to donate the blood [30]. According to a WHO report in 2016, in Kyrgyzstan, HBsAg screening is performed on donated blood samples [21]. The decree adopted by the government of the Russian Federation in 2010 states that all donated blood should be screened for HBsAg [31]. If the result of the screening is positive, the serological screening is repeated two more times under the same conditions. If one of the two consecutive tests is positive, the donated blood sample should undergo confirmation with an HBsAg neutralization reaction. At the same time, each sample is screened with NAT using PCR-based tests, especially for the blood components with a short shelf life and for fresh frozen plasma that has not been quarantined. If the test is negative, it is repeated two more times under the same settings. The sample is considered positive for HBV, if at least one of the tests is positive [31]. In Tajikistan, according to government decree, all donated blood is screened for HBV using ELISA- and PCR-based testing, [27]. In Turkmenistan and Uzbekistan, no specific HBV tests are enforced by the local screening regulations adopted in 2017 [32] and 2014 [33], respectively (Table 2). Stringent regulations for blood donor screening are being implemented in Kazakhstan, Kyrgyzstan, the Russian Federation, and Tajikistan. The testing protocols employ detection of both HBsAg and HBV nucleic acid, using a multistep algorithm to ensure that all potentially HBV-infected donors are effectively screened out.

Table 2. Screening for HBV in blood donors. Sources of information are mentioned in parenthesis; n/a, not available.

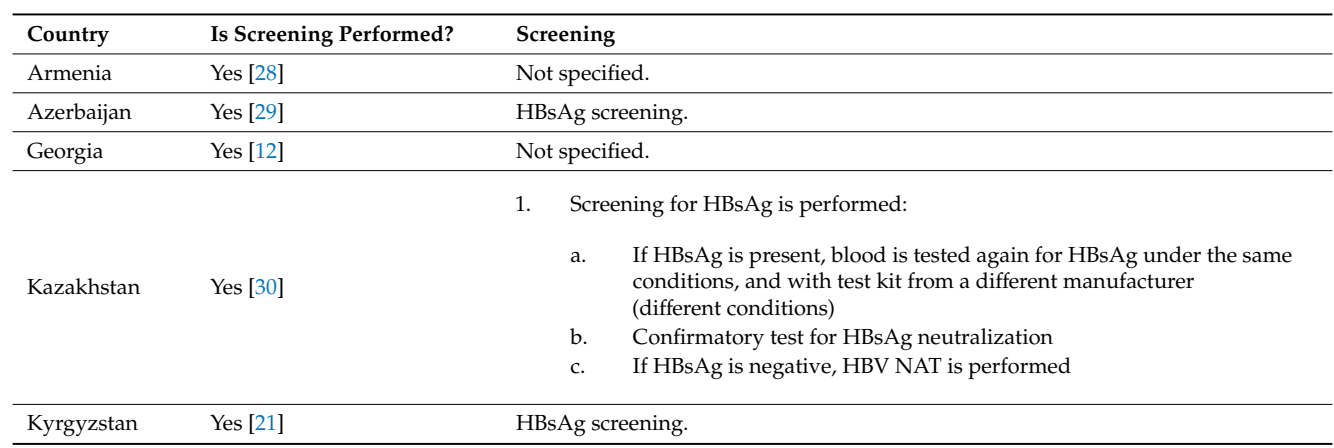


Table 2. Cont

\begin{tabular}{|c|c|c|c|}
\hline Country & Is Screening Performed? & Screenin & \\
\hline \multirow{5}{*}{$\begin{array}{l}\text { Russian } \\
\text { Federation }\end{array}$} & \multirow{5}{*}{ Yes [31] } & Scre & ning for HBsAg is performed: \\
\hline & & \multirow{4}{*}{2.} & $\begin{array}{l}\text { If HBsAg is present, the test is repeated two times under the } \\
\text { same conditions }\end{array}$ \\
\hline & & & $\begin{array}{l}\text { If at least one test is positive, the sample is confirmed with } \mathrm{HBsAg} \\
\text { neutralization reaction }\end{array}$ \\
\hline & & & $\begin{array}{l}\text { ltaneously, each sample is screened with PCR-based tests. This test is } \\
\text { rmed for blood components with short shelf life and fresh frozen plasma } \\
\text { vas not quarantined: }\end{array}$ \\
\hline & & & $\begin{array}{l}\text { If negative, the test is performed } 2 \text { times with the same settings. If at } \\
\text { least one test is positive, sample is considered } \mathrm{HBV} \text { positive }\end{array}$ \\
\hline Tajikistan & Yes [27] & \multicolumn{2}{|c|}{$\begin{array}{l}\text { Not specified. } \\
\text { National program is aimed to introduce both ELISA- and PCR-based test systems. }\end{array}$} \\
\hline Turkmenistan & Yes [32] & \multicolumn{2}{|l|}{$\mathrm{n} / \mathrm{a}$} \\
\hline
\end{tabular}

\section{HBV Vaccination}

In Armenia, the HBV vaccine was introduced in 1999, and the birth dose was instituted the same year [34]. The vaccine is monovalent, with three doses scheduled at 0,6 , and 26 weeks after birth [11]. For 2018, the vaccine coverage rate for the birth dose was estimated at $97 \%$, while for the third dose it was estimated at 92\% [34] (Table 3). In Azerbaijan, the HBV vaccine and its birth dose were implemented in 2001 [34]. The vaccine is monovalent and is given at 0, 9, and 17 weeks after birth [11]. In 2018, the hepatitis B vaccine coverage rate in Azerbaijan was $99 \%$ for the birth dose, and $95 \%$ for the third dose [34]. In Georgia, the vaccine was introduced in 2001, however the birth dose was implemented two years later, in 2003 [34]. The vaccine is scheduled at 0, 8, 12, and 16 weeks after birth [35]. A dose given at birth is monovalent, and the other three are pentavalent [35]. In 2018, the vaccine coverage rate for the birth dose was estimated at 97\%, however, for the third dose it was estimated at 93\% [34]. In Kazakhstan, HBV vaccination was initiated in 1998, and the birth dose was instituted in the same year [34]. The vaccine is given in three doses: a monovalent dose at birth, and tetravalent at 8 and 16 weeks after birth [36]. In 2018, the vaccine coverage rate for the birth dose was 95\%, and for the third dose it was $98 \%$ in 2018 [34]. In Kyrgyzstan, the hepatitis B vaccine was implemented in 2001, while the birth dose was introduced in 1998 [34]. The vaccine is scheduled at $0,8,14$, and 24 weeks after birth: a dose given at birth is monovalent, the other three are pentavalent [21]. In 2017, the vaccine coverage rate for the birth dose was estimated at $97 \%$, while for the third dose at $92 \%$ [34]. In the Russian Federation, the HBV vaccine and its birth dose were implemented in 2000 [34]. The vaccine is monovalent and scheduled at 0, 4, and 24 weeks after birth [37]. However, one additional dose is recommended for children born to high-risk parents; the vaccine being scheduled at $0,4,8$, and 48 weeks after birth [37]. High-risk parents include women who are drug abusers or HBsAg-carriers, who have hepatitis B or have suffered from it in the third trimester, those not tested for hepatitis B prenatally, or who have a family history of HBV infection [37]. In 2013, the reported vaccine coverage rate for the third dose was 97\% [34]. In Tajikistan, the hepatitis B vaccine was instituted in 2002, while its birth dose was introduced in 1998 [34]. The vaccine is monovalent and is scheduled at 0, 9, and 17 weeks after birth [11]. In 2018, the vaccine coverage rate for the birth dose was estimated at 99\%, and for the third dose at 96\% [34] (Table 3). In Turkmenistan, the hepatitis B vaccine and its birth dose were implemented in 2002 [34]. In 2018, the vaccine coverage rate for the birth dose and the third dose was estimated at $99 \%$ [34]. The vaccine is given at $0,8,12$, and 16 weeks after birth [38]. The dose given at birth is monovalent, while the others are pentavalent [38]. In Uzbekistan, the hepatitis B vaccine was implemented in 2001, however, its birth dose was introduced three years earlier, in 1998 [34]. The vaccine is given at $0,8,12$, and 16 weeks after birth [39]. A dose given at birth is monovalent, while the other three doses are pentavalent [39]. In 2018, the vaccine coverage rate for the birth dose was 95\%, while for the third dose it was 98\% [34] (Table 3). Overall, vaccine coverage in the region appears to be satisfactory. Especially for Azerbaijan, Kazakhstan, Tajikistan, Turkmenistan, and Uzbekistan, the coverage of birth and the third dose is reported, impressively, to be between $95 \%$ and $99 \%$. 
Table 3. Implementation of HBV vaccination in the countries of Central Asia and the Caucasus. All the data were retrieved from the source [34], except for the information on vaccine type and schedule, for which the sources of information are mentioned in parenthesis.

\begin{tabular}{|c|c|c|c|c|c|}
\hline Country & $\begin{array}{c}\text { Year of Vaccine } \\
\text { Introduced in Entire } \\
\text { Country }\end{array}$ & $\begin{array}{l}\text { Year of Birth Dose } \\
\text { Introduced }\end{array}$ & $\begin{array}{l}\text { Coverage of Birth } \\
\text { Dose in } 2018, \%\end{array}$ & $\begin{array}{l}\text { Coverage of 3rd Dose } \\
\text { in } 2018, \%\end{array}$ & $\begin{array}{c}\text { Type of } \\
\text { Vaccine/Schedule in } \\
\text { Weeks }\end{array}$ \\
\hline Armenia & 1999 & 1999 & 97 & 92 & $\begin{array}{l}\text { Monovalent vaccine given } \\
\text { at } 0,6,26 \text { weeks [11]. }\end{array}$ \\
\hline Azerbaijan & 2001 & 2001 & 99 & 95 & $\begin{array}{l}\text { Monovalent vaccine given } \\
\text { at } 0,9,17 \text { weeks [11]. }\end{array}$ \\
\hline Georgia & 2001 & 2003 & 97 & 93 & $\begin{array}{l}\text { Monovalent vaccine given } \\
\text { at birth [35]; } \\
\text { Pentavalent vaccine given } \\
\text { at } 8,12,16 \text { weeks [35]. }\end{array}$ \\
\hline Kazakhstan & 1998 & 1998 & 95 & 98 & $\begin{array}{l}\text { Monovalent vaccine given } \\
\text { at birth [36]; } \\
\text { Tetravalent vaccine given } \\
\text { at } 8 \text { and } 16 \text { weeks [36]. }\end{array}$ \\
\hline Kyrgyzstan & 2001 & 1998 & 97 & 92 & $\begin{array}{l}\text { Monovalent vaccine given } \\
\text { at birth [21]; } \\
\text { Pentavalent vaccine given } \\
\text { at } 8,14,24 \text { weeks [21]. }\end{array}$ \\
\hline $\begin{array}{l}\text { Russian } \\
\text { Federation }\end{array}$ & 2000 & 2000 & $\mathrm{n} / \mathrm{a}$ & 97 & $\begin{array}{c}\text { Monovalent vaccine given } \\
\text { at } 0,4,24 \text { weeks OR at } 0,4, \\
8,48 \text { weeks [37]. }\end{array}$ \\
\hline Tajikistan & 2002 & 1998 & 99 & 96 & $\begin{array}{l}\text { Monovalent vaccine given } \\
\text { at } 0,9,17 \text { weeks [11]. }\end{array}$ \\
\hline Turkmenistan & 2002 & 2002 & 99 & 99 & $\begin{array}{l}\text { Monovalent vaccine given } \\
\text { at birth [38]; } \\
\text { Pentavalent vaccine given } \\
\text { at } 8,12,16 \text { weeks [38]. }\end{array}$ \\
\hline Uzbekistan & 2001 & 1998 & 95 & 98 & $\begin{array}{l}\text { Monovalent vaccine given } \\
\text { at birth [39]; } \\
\text { Pentavalent vaccine given } \\
\text { at } 8,12,16 \text { weeks [39]. }\end{array}$ \\
\hline
\end{tabular}




\section{Treatment for HBV}

With the exception of Georgia and Turkmenistan, for all the countries of Central Asia and the Caucasus, clinical guidelines for the treatment of HBV infection are either available online or in the report of the Alliance for Public Health [9] (Table 4). Lists of the antiviral medications used in each country are available online, except for Turkmenistan. According to a 2015 WHO report, the drugs approved for the treatment of the chronic hepatitis B infection include: lamivudine, adefovir, entecavir, telbivudine, tenofovir, emtricitabine, and standard and pegylated interferon (PEG-IFN) [40]. However, according to $\mathrm{WHO}$, standard and pegylated interferon are not recommended for the lowand middle-income countries, due to their high cost. Interestingly, contrary to this recommendation, all the Central Asian and the Caucasus countries, except for Azerbaijan and Kyrgyzstan (where an official clinical protocol is not available), use interferon as the antiviral medication (Table 4). Aside from Turkmenistan, all the countries use at least one of the nucleos $(t)$ ide inhibitors recommended by WHO.

Table 4. Implementation of HBV treatment in the countries of Central Asia and the Caucasus. n/a, not available.

\begin{tabular}{lll}
\hline Country & $\begin{array}{l}\text { Implementation of Treatment } \\
\text { Protocol }\end{array}$ & Antiviral Medications Available in the Country \\
\hline Armenia & Yes [9] & Interferon alpha, pegylated interferon, lamivudine [41] \\
\hline Azerbaijan & Yes [9] & Lamivudine, lamivudine generic, tenofovir [9] \\
\hline Georgia & n/a & $\begin{array}{l}\text { Interferon alpha, pegylated interferon, lamivudine, adefovir } \\
\text { dipivoxil and tenofovir [41] }\end{array}$ \\
\hline Kazakhstan & Yes [9] & $\begin{array}{l}\text { Pegylated interferon alpha, tenofovir disoproxil fumarate, } \\
\text { tenofovir alafenamide fumarate, entecavir [42] }\end{array}$ \\
\hline Kyrgyzstan & Yes [9] & $\begin{array}{l}\text { Lamivudine generic, entecavir generic, tenofovir, tenofovir } \\
\text { generic, emtricitabine, emtricitabine generic [9] }\end{array}$ \\
\hline $\begin{array}{l}\text { Russian } \\
\text { Federation }\end{array}$ & Yes [9] & $\begin{array}{l}\text { Pegylated interferon alpha, lamivudine, entecavir, tenofovir, } \\
\text { telbivudine [43] }\end{array}$ \\
\hline Tajikistan & Yes [9] & $\begin{array}{l}\text { Interferon alpha, pegylated interferon, adefovir, entecavir, } \\
\text { emtricitabine, lamivudine, tenofovir, telbivudine [44] }\end{array}$ \\
\hline Turkmenistan & n/a & \begin{tabular}{l} 
n/a \\
\hline Uzbekistan
\end{tabular} \\
Yes [9] & $\begin{array}{l}\text { Interferon alpha, pegylated interferon [44] } \\
\text { Lamivudine generic, tenofovir generic, emtricitabine } \\
\text { generic [9] }\end{array}$ \\
\hline
\end{tabular}

\section{Conclusions}

Overall, in Central Asia and the Caucasus, the prevalence of HBV and associated co-infections has been declining, owing to rigorous implementation of vaccination, treatment, and blood donor screening protocols. Thorough and large-scale surveys are key to recording evolving trends in the prevalence and transmission of infections. While regular surveys are being carried out by countries such as Armenia, Azerbaijan, Georgia, and Kazakhstan, certain exceptions still exist. Another area of focus is to enhance public accessibility of the information related to data, as well as policies regarding HBV infection and its control. For the prevalence of HBV single and co-infection, information was readily available from Azerbaijan, Georgia, and Kyrgyzstan, while from the rest of the countries this information was either partially available or unavailable. Additionally commendable is the full disclosure of information regarding blood-screening protocols by Kazakhstan, Kyrgyzstan, the Russian Federation, and Tajikistan. It appears, therefore, that in certain countries the information, while it may exist, is not readily available for review or scrutiny, compromising the transparency of the process. 
Author Contributions: D.A.: Conceptualization, original draft preparation, literature search; I.S.: writing, review and editing; S.D.: Formal analysis, resources, literature search; Z.N.: supervision, review; S.A.: review and editing, supervision, project administration, funding acquisition. All authors have read and agreed to the published version of the manuscript.

Funding: S.A. received funding for this study from Nazarbayev University under the grant: 110119FD4516, and from the National Institute on Drug Abuse of the National Institute of Health under Award Number R03DA052179. The content is solely the responsibility of the authors and does not necessarily represent the official views of Nazarbayev University or the National Institute of Health.

Conflicts of Interest: The authors declare no conflict of interest.

\section{References}

1. Burke, J. Post-Soviet World: What You Need to Know about the 15 States. The Guardian. 2014. Available online: https://www.theguardian.com/world/2014/jun/09/-sp-profiles-post-soviet-states (accessed on 24 July 2020).

2. Gvozdetsky, N.A.; Bruk, S.I.; Owen, L. Caucasus. Encyclopædia Britannica. 2019. Available online: https://www.britannica.com/place/Caucasus (accessed on 22 July 2020).

3. Hermann, W.; Linn, J. (Eds.) Central Asia and the Caucasus: At the Crossroads of Eurasia in the 21st Century; SAGE Publications: New Delhi, India, 2011.

4. Worldometer. Countries in the World by Population. 2020. Available online: https://www.worldometers. info/world-population/population-by-country/ (accessed on 20 June 2020).

5. YourFreeTemplates.com. Free Central Asia and Caucasus Editable Map. 2017. Available online: https: //yourfreetemplates.com/free-central-asia-caucasus-editable-map/ (accessed on 20 June 2020).

6. Lazarus, J.V.; Shete, P.B.; Eramova, I.; Merkinaite, S.; Matic, S. HIV/hepatitis coinfection in eastern Europe and new pan-European approaches to hepatitis prevention and management. Int. J. Drug Policy 2007, 18, 426-432. Available online: https://www.sciencedirect.com/ science/article/pii/S0955395907000126?casa_token=S0AA2MLiC2QAAAAA:HCRgbtBPWa2np3X_ i1NTV8HVBpSf9pPQnUqbbu1ybPi0axUEtfWJfbWieYXJGHOTc0R_vBaP4Mg (accessed on 24 June 2020). [CrossRef] [PubMed]

7. Demirchyan, A.; Mirzoyan, L.; Thompson, M.E. Synthesis of the Existing Data on Hepatitis B in Armenia; American University of Armenia: Yerevan, Armenia, 2000.

8. Ghazinyan, H.; Asoyan, A.; Mkhitaryan, A.; Melik-Andreasyan, G. Updating HBV status in Armenia. In Proceedings of the EASL Special Conference: Optimal Management of HBV infection, Athens, Greece, 25-27 September 2014; Available online: https:/livertree.easl.eu/easl/2014/athens/62141/hasmik.levon.ghazinyan. updating.hepatitis.b.virus.(hbv).status.in.armenia.html?f=p6m3e757 (accessed on 1 August 2020).

9. Kravchenko, N.; Maistat, L.; Golovin, S.; Nikelsen, T.; Aliyev, A.; Harantyunyan, A.; Biryukov, S.; Gulov, K.; Jamolov, P.; Pashaev, E.; et al. Otchet “Gepatit V i S v regione Vostochnoŭ Evropy i TSentral'noŭ Azii: Epidemiia i Otvetnye Mery". 2017. Available online: http://mv.ecuo.org/download/otchet-gepatit-v-i-s-vregione-vostochnoj-evropy-i-tsentralnoj-azii-epidemiya-i-otvetnye-mery/ (accessed on 1 August 2020).

10. Mamedov, M.; Dadasheva, A.; Kadyrova, A.; Tagizade, R.; Mikhailov, M. Serologicheskie Markery Infektsii, Vyzvannykh Virusami Gepatitov v i s, u Zhiteleŭ Azerbaĭdzhana iz Grupp s Vysokim Riskom Parenteral'nogo Infitsirovaniia [Serological Markers of Infections Caused by Hepatitis B and C Viruses in Residents of Azerbaijan from Groups with a High Risk of Parenteral Infection]. Épidemiologiia vaktsinoprofilaktika 2012, 2, 63. Available online: https://cyberleninka.ru/article/n/serologicheskie-markery-infektsiy-vyzvannyh-virusami-gepatitov-v-i-s-uzhiteley-azerbaydzhana-iz-grupp-s-vysokim-riskom-parenteralnogo (accessed on 24 June 2020).

11. Schweitzer, A.; Akmatov, M.K.; Krause, G. Hepatitis B vaccination timing: Results from demographic health surveys in 47 countries. Bull. World Health Organ. 2017, 95, 199. Available online: https://www.ncbi.nlm.nih. gov/pmc/articles/PMC5328113/ (accessed on 24 June 2020). [CrossRef] [PubMed]

12. Butsashvili, M.; Tsertsvadze, T.; McNutt, L.; Kamkamidze, G.; Gvetadze, R.; Badridze, N. Prevalence of hepatitis B, hepatitis C, syphilis and HIV in Georgian blood donors. Eur. J. Epidemiol. 2001, 17, 693-695. Available online: https://ink.springer.com/article/10.1023/A:1015566132757 (accessed on 24 June 2020). [CrossRef] [PubMed] 
13. Stvilia, K.; Meparidze, M.; Tsertsvadze, T.; Sharvadze, L.; Dzigua, L. Prevalence of HBV and HCV infections and high risk behavior for blood born infections among general population of Tbilisi, Georgia. Ann. Biomed. Res. Educ. 2005, 5, 289-298. Available online: http://citeseerx.ist.psu.edu/viewdoc/download? (accessed on 24 June 2020).

14. Khochava, M.; Shalamberidze, I.; Jokhtaberidze, T. Problema B i C gepatitov i ikh Registratsii v Gruzii [The Problem of B and C Hepatitis and Their Registration in Georgia]. 2013. Available online: http: //elib.grsmu.by/handle/files/15779 (accessed on 24 June 2020).

15. Badridze, N.; Chkhartishvili, N.; Abutidze, A.; Gatserelia, L.; Sharvadze, L. Prevalence of hepatitis B and C among HIV positive patients in Georgia and its associated risk factors. Georgian Med. News, 2008; 165, 54-60. Available online: https://pubmed.ncbi.nlm.nih.gov/19124918/(accessed on 24 June 2020).

16. Skorikova, S.V.; Burkitbaev, L.; Savchuk, T.; Zhiburt, E. Rasprostranennost' VICH-, VGS-, VGV-infektsiı̆ $\mathrm{u}$ donorov krovi g. Astany [Prevalence of HIV, HCV, HBV Infections among Blood Donors in Astana]. Voprosy Virusologii 2015, 60. Available online: https://cyberleninka.ru/article/n/rasprostranennost-vich-vgsvgv-infektsiy-u-donorov-krovi-g-astany (accessed on 24 June 2020).

17. Hope, V.; Eramova, I.; Capurro, D.; Donoghoe, M. Prevalence and estimation of hepatitis B and C infections in the WHO European Region: A review of data focusing on the countries outside the European Union and the European Free Trade Association. Epidemiol. Infect. 2014; 142, 270-286. Available online: https://pubmed.ncbi.nlm.nih.gov/23714072/(accessed on 24 June 2020). [CrossRef] [PubMed]

18. Savchuk, T.; Greenwald, E.; Ilyasova, N. Rezul'taty Avtomatizatsii Laboratornogo Skrininga Donorskoı̆ Krovi na Gemotransmissivnye Infektsii v Respublike Kazahstan. Res. Prod. Cent. Transfus. 2015, 29. Available online: https://spct.kz/specialist/ (accessed on 24 June 2020).

19. Nersesov, A.; Berkinbaev, S.; Dzhunusbekova, H.; Dzhumabayeva, A.; Novitskaya, M.; Kuanish, N. Rasprostranennost' VirusnyhGepatitov Sredi Zhiteleı̆ Iuzhno-Kazahstanskoŭ Oblasti [Prevalence of Viral Hepatitis among Residents of the South Kazakhstan Region]. Medicine 2016, 9, 30-33. Available online: http://www.medzdrav.kz/index.php/ (accessed on 24 June 2020).

20. Karabaev, B.B.; Beisheeva, N.J.; Satybaldieva, A.B.; Ismailova, A.D.; Pessler, F.; Akmatov, M.K. Seroprevalence of hepatitis B, hepatitis $C$, human immunodeficiency virus, Treponema pallidum, and co-infections among blood donors in Kyrgyzstan: A retrospective analysis (2013-2015). Infect. Dis. Poverty 2017, 6, 45. Available online: https://link.springer.com/article/10.1186/s40249-017-0255-9 (accessed on 24 June 2020). [CrossRef] [PubMed]

21. Mozalevskis, A.; Harmanci, H.; Bobrik, A. Assessment of the Viral Hepatitis Response in Kyrgyzstan, 11-15 July 2016; World Health Organization: Copenhagen, Denmark, 2017; Available online: https://www.euro.who.int/en/countries/kyrgyzstan/publications/assessment-of-the-viral-hepatitisresponse-in-kyrgyzstan,-1115-july-2016-2017 (accessed on 24 June 2020).

22. Klushkina, V.V.; Kyuregyan, K.K.; Kozhanova, T.V.; Popova, O.E.; Dubrovina, P.G.; Isaeva, O.V.; Gordeychuk, I.V.; Mikhailov, M.I. Impact of universal hepatitis B vaccination on prevalence, infection-associated morbidity and mortality, and circulation of immune escape variants in Russia. PLoS ONE 2016, 11, e0157161. Available online: https://journals.plos.org/plosone/article?id=10.1371/journal.pone. 0157161 (accessed on 24 June 2020). [CrossRef] [PubMed]

23. Alsalikh, N.; Sychev, D.; Potemkin, I.; Kyureghian, K.; Mikhailov, M. Rasprostranennost' serologicheskikh markerov virusnykh gepatitov sredi trudovykh migrantov, pribyvaiushchikh v Rossiǔskuiu Federatsiiu [Prevalence of serological markers of viral hepatitis among labor migrants arriving in the Russian Federation]. Zhurnal Infektologii 2017, 9, 80-85. Available online: https://journal.niidi.ru/jofin/article/view/604 (accessed on 24 June 2020). [CrossRef]

24. Shukurov, A.; Begendjova, M.; Atamuradova, L.; Shayimov, B.; Ibragimov, M. Epidemiological characteristics of the spread of hepatitis C in Turkmenistan. Young Sci. 2018, 40, 115-119. Available online: https: //elibrary.ru/item.asp?id=36066614 (accessed on 24 June 2020).

25. European Centre for Disease Prevention and Control. Monitoring the Responses to Hepatitis B and C Epidemics in EU/EEA Member States, 2019 Stockholm: ECDC. 2020. Available online: https://www.ecdc.europa.eu/en/publicationsdata/monitoring-responses-hepatitis-b-and-c-epidemics-eueea-member-states-2019 (accessed on 24 August 2020). 
26. Zeynalova, K. Virusnye gepatity V i S: èpidemiologicheskaia situatsiia v Azerbaĭdzhane v poslednie gody [Viral hepatitis B and C: Epidemiological situation in Azerbaijan in recent years]. Épidemiol. Vaktsinoprofil. 2010, 4. Available online: https://cyberleninka.ru/article/n/virusnye-gepatity-v-i-s-epidemiologicheskayasituatsiya-v-azerbaydzhane-v-poslednie-gody (accessed on 24 June 2020).

27. Postanovlenie Pravitel'stva Respubliki Tadzhikistan ot 2 iiulia 2015 Goda No. 422. O Natsional'no Programme po Razvitiiu Donorstva Krovi i eë Komponentov v Respublike Tadzhikistan na 2015-2019 Gody. 2016. Available online: https://online.zakon.kz/Document/?doc_id=35408765 (accessed on 24 June 2020).

28. Vershinina, N.; Golosova, S.; Daykhes, N.; Dorunova, N.; Stefanyuk, Y.; Eykhler, O. Opyt Zarubezhnih Stran v Reshenii Voprosov Donorstva Krovi. Informatsionno-Metodicheskoe Posobie v Pomoshch' Organizatoram Donorskogo Dvizheniia [Informational-Methodical Manual to Help the Organizers of the Donor Movement]. 2016. Available online: http://spasibodonor.ru/wp-content/uploads/2016/11/Zarubezh_donorstvo_preview. pdf (accessed on 24 June 2020).

29. Asadov, C. Present and Future of Transfusion Medicine in the Countries of Far-Eastern Europe and Central Asia. 2011. Available online: https://www.researchgate.net/publication/239979407_PRESENT_AND_ FUTURE_OF_TRANSFUSION_MEDICINE_IN_THE_COUNTRIES_OF_FAR-EASTERN_EUROPE_ AND_CENTRAL_ASIA_Chingiz_Asadov_Baku_Azerbaijan (accessed on 24 June 2020).

30. Ob utverzhdenii Trebovaniı̌ k Meditsinskomu Osvidetel'Stvovaniiu Donorov, Bezopasnosti i Kachestvu pri Proizvodstve Produktov Krovi Dlia Meditsinskogo Primeneniia. Prikaz Ministra Zdravookhraneniia Respubliki Kazakhstan ot 15 Aprelia 2019 Goda № KR DSM-34. Zaregistrirovan v Ministerstve Iustitsii Respubliki Kazakhstan 16 Aprelia 2019 Goda № 18524. 2019. Available online: http://adilet.zan.kz/rus/docs/ V1900018524 (accessed on 24 June 2020).

31. Postanovlenie Pravitel'stva RF ot 31 Dekabria 2010 g. N 1230 “Ob Utverzhdenii Pravil i Metodov Issledovaniı i Pravil Otbora Obraztsov Donorskoŭ Krovi, Neobkhodimykh dlia Primeneniia i Ispolneniia Tekhnicheskogo Reglamenta o Trebovaniiakh Bezopasnosti Krovi, ee Produktov, Krovezameshchaiushchikh Rastvorov i Tekhnicheskikh Sredstv, Ispol'zuemykh v Transfuzionno-Infuzionnol̆ terapii". 2011. Available online: http://www.garant.ru/products/ipo/prime/doc/12081836/ (accessed on 24 June 2020).

32. Zakon Turkmenistana o Donorstve Krovi. 2017. Available online: https://www.parahat.info/law/parahatinfo-law-01zs (accessed on 24 June 2020).

33. Prikazom Ministra Zdravookhraneniia (Zaregistrirovan MIU 15.01.2014 g. № 2556) Utverzhdeno Polozhenie o Poriadke Sdachi Krovi i ee Komponentov. 2014. Available online: https://minzdrav.uz/m/docs/detail/36281/ (accessed on 24 June 2020).

34. World Health Organization. Immunization, Vaccines and Biologicals. Data, Statistics and Graphics. [updated 7 June 2020]. 2020. Available online: https://www.who.int/immunization/monitoring_surveillance/data/en/ (accessed on 24 June 2020).

35. Kalendar' Privivok v Gruzii Sputnik Georgia. 2017. Available online: https://sputnik-georgia.ru/infographics/ 20171010/237693326/kalendar-privivok-v-gruzii.html (accessed on 20 July 2020).

36. Ob Utverzhdenii Perechnia Zabolevanii, Protiv Kotorykh Provodiatsia Profilakticheskie Privivki, Pravil ikh Provedeniia i Grupp Naseleniia, Podlezhashchikh Planovym Privivkam. 2009. Available online: http://adilet.zan.kz/rus/docs/P090002295_\#z12 (accessed on 13 July 2020).

37. Prikaz Ministerstva Zdravookhraneniia RF ot 21 Marta 2014 g. N 125n “Ob Utverzhdenii Natsional'nogo Kalendaria Profilakticheskikh Privivok i Kalendaria Profilakticheskikh Privivok po Epidemicheskim Pokazaniiam" (s Izmeneniiami i Dopolneniiami). 2014. Available online: https://base.garant.ru/70647158/ (accessed on 13 July 2020).

38. Yagudina, T. Turkmenistan Rasshiriaet Kalendar' Privivok, Soglasno Rekomendatsiiam VOZ. 2020. Available online: https://arzuw.news/turkmenistan-rasshirjaet-kalendar-privivok-soglasno-rekomendacijam-voz (accessed on 19 July 2020).

39. Saydaliev, S.; Tursunova, Y.; Khalilova, G.; Mullaeva, L.; Mirzabaev, D.; Kim, L. Sanitarnye Pravila, Normy, Gigienicheskie Normativy, Immunoprofilaktika, Infektsionnykh Zabolevaniǔ v Respublike Uzbekistan. 2015. Available online: https://www.minzdrav.uz/documentation/detail.php?ID=45175 (accessed on 19 July 2020).

40. World Health Organization. Guidelines for the Prevention Care and Treatment of Persons with Chronic Hepatitis B Infection: Mar-15; World Health Organization: Geneva, Switzerland, 2015. 
41. World Health Organization. Global policy report on the prevention and control of viral hepatitis in WHO Member States. 2013. Available online: https://www.who.int/hepatitis/publications/global_report/en/ (accessed on 19 July 2020).

42. Republican Center for Healthcare Development of the Ministry of Health of the Republic of Kazakhstan. Chronic Hepatitis B in Adults. 2019 [Updated 19 November 2019]. Available online: https://diseases. medelement.com/disease/2019/16388 (accessed on 19 July 2020).

43. Ivashkin, V.; Yushchuk, N.; Mayevskaya, M.; Znojko, O.; Dudin, K.; Karetkina, G.; Klimova, S.L.; Maksimov, Y.V.; Martynov, I.V.; Maev, H.S.; et al. Mezhdunarodnaia Koalitsiia po Gotovnosti k Lecheniiu Vostochnaia Evropa i TSentral'naia Aziia. Klinicheskiǔ Protokol Respubliki Tadzhikistan “Gepatit V i VICH-infektsiia: Taktika Vedeniia Patsientov s Koinfektsieı̌”. 2011. Available online: https:/itpcru.org/2015/09/16/13495/ (accessed on 19 July 2020).

44. Ministerstvo Zdravookhraneniia Respubliki Uzbekistan. Klinicheskoe Rukovodstvo po Diagnostike, Lecheniiu i Profilaktike Khronicheskikh Gepatitov u Vzroslykh v Pervichnom Zvene Zdravookhraneniia. 2013. Available online: https:/www.minzdrav.uz/documentation/detail.php?ID=41092 (accessed on 19 July 2020). (In Russian).

(C) 2020 by the authors. Licensee MDPI, Basel, Switzerland. This article is an open access article distributed under the terms and conditions of the Creative Commons Attribution (CC BY) license (http://creativecommons.org/licenses/by/4.0/). 